\title{
低炭素鋼の疲労強度特性に及ぼす繰返し速度の影響*
}

\author{
堤 紀 子*1, 城 本 \\ 晃*2 \\ Veronique DOQUET ${ }^{* 3}$, 村 上 敬 宜*4
}

\section{Effect of Test Frequency on Fatigue Strength of Low Carbon Steel}

Noriko TSUTSUMI, Akira SHIROMOTO, Veronique DOQUET and Yukitaka MURAKAMI*5

${ }^{* 5}$ Department of Mechanical Engineering Science, Kyushu University,

744 Motooka, Nishi-ku, Fukuoka-shi, Fukuoka, 819-0395 Japan

The ultrasonic fatigue tests (test frequency : $20 \mathrm{kHz}$ ) and the conventional tension compression fatigue tests $(10 \mathrm{~Hz})$ have been conducted using the annealed and $10 \%$ pre-strained specimens of $0.13 \%$ carbon steel. Two small artificial holes (diameter and depth : $100 \mu \mathrm{m}$ ) were introduced onto the specimen surface to invistigate the effect of test frequency on the crack initiation and growth behavior. In order to suppress the temperature rise of the ultrasonic fatigue specimens, the intermittent ultrasonic loading method and the air cooling were used. The dynamic stress concentration factor and the stress intensity factor under the ultrasonic fatigue tests were calculated. It has been revealed that the dynamic stress concentration factors for a small circular hole and a small spherical cavity and the dynamic stress intensity factor for a penny-shaped crack are almost the same as those at low strain rates from the conventional tension compression fatigue tests. On the other hand, the fatigue properties were dependent on the test frequency. The ultrasonic fatigue tests showed longer fatigue life and lower fatigue crack growth rate for the annealed and $10 \%$ pre-strained specimens. The evident slip bands were not observed in the neighborhood of the crack in the annealed specimen uuder the ultrasonic fatigue tests, while the slip bands were observed in the wide area around the crack under the conventional fatigue tests. Slip bands were observed slightly in the $10 \%$ pre-strained specimen under the ultrasonic fatigue tests. In order to determine the stress-strain curve for $0.13 \%$ carbon steel under the high strain rates, the Split Hopkinson Bar tests were carried out. The yield stress and deformation stress were increased with the strain rate. Thus, the effect of test frequency on fatigue strength can be explained from the viewpoint of the effect of test frequency on fatigue crack growth for $0.13 \%$ carbon steel.

Key Words: Fatigue, Ultrasonic Fatigue Test, Stress Wave, Test Frequency, Low Carbon Steel, Crack Propagation, Stress Concentration Factor, Stress Intensity Factor, Split Hopkinson Bar Test

\section{1. 緒碖}

従来, $10^{7}$ 回の一定繰返し応力に耐えた鉄鋼材料は それ以上絽返し応力を負荷しても破断しないといわれ ていた。材料が 10 回の繰返しに耐える最大の応力振 幅を疲労限度といい，機械・構造物の疲労強度設計の 重要な基本データとして利用されている. しかしなが ら, 内藤ら ${ }^{()}$, Naito $ら^{(9)}$ の研究により, 高強度鋼は綝 返し数 $N>10^{7}$ でも疲労破壊が起こる場合があることが 報告された. 江村・浅見 ${ }^{()}$, 阿部・金澤仙は $N>10^{7}$ での 疲労破壊は材料内部の非金属介在物を起点とするもの であることを報告している，村上らのは非金属介在物

* 原稿受付 2005 年 7 月 11 日.

*1 正員, 九州大学大学院工学府 ( 819-0395 福岡市西区元岡 744).

*2 本田技研工業(株) ( 107-8556 東京都港区南青山 2-1-1) [元 : 九州大学大学院工学府].

${ }^{* 3}$ Ecole Polytechnique (91128 Palaiseau Cedex U.R.A. C.N. R.S. 317, France).

*4 正員, 九州大学大学院工学研究院.

E-mail : ymura@ mech.kyushu-u.ac.jp
周辺にトラップされた水素が $N>10^{7}$ の疲労破壊を引き 起こすことを指摘している. また, アルミニウム合金 などの非鉄金属では鉄鋼材料のようにき裂が停留現象 を示すことがなく $N>10^{7}$ でも疲労破壊が起こること か知られている.このような事情で，機械・構造物の 長期間使用に対する安全性およひ信頼性を保証するに は $N>10^{7}$ の疲労デー夕を得ることが必要となっている. しかし, 通常の疲労試馬㑒機で $N>10^{7}$ の疲労デ一夕を得 るには非常に長い時間を要する. 例えば, $N=10^{\circ}$ まで の疲労試験を行う場合, 繰返し速度 $101 \mathrm{t} て ゙ は$ 約 3 年, $1001 女$ でも 4 ヶ月かかる. そのため, 試験時間短縮を 目的として高い絽返し速度で疲労試験を行うことがで きる超音波度労試験機の使用か試みられている. 絽返 し速度 20kњ女の超音波疲労試験機を使用すると，約 14 時間で $N=10^{9}$ を達成することができる．しかしながら， 超音波疲労試験は繰返し速度が非常に高いので, 試験 片の発熱およひ度労強度に及ぼす繰返し速度の影響が 
問題となっている. 疲労強度の絽返し速度依存性につ いてはいくつかの研究か行われており, 高強度釦の, チタン合金(の)およびアルミニウム合金(では繰返し 速度の影響は小さいといわれている. 著者らのアルミ ニウム合金に関する研究(3)では, $N<10^{7}$ の領域で超音 波疲労試験(繰返し速度 $20 \mathrm{kH}$ ) と通常の引張圧縮疲労 試験(50-80H飞)疲労寿命はほぼ一致した。一方, $N>10^{7}$ の領域で超音波度労試験の疲労寿命は通常の引張圧縮 疲労試馬㑒の数十倍であった. 軟鋼の疲労強度に及ぼす 繰返し速度の影響についてもいくつか研究が行われて いる(4)(9).純鉄や軟鋼では，綝返し速度が高いほと疲 労強度も高いことを粟谷・片桐はは報告している.こ の原因は転位運動がひずみ速度に追従できないことに よるといわれている. そこで, 切欠きをつけ, 疲労き 裂准展が疲労寿命の大部分を占めるようにすると, ひ ずみが切欠き底やき裂先端に集中するので，転位運動 がひずみ速度に追従できなくなる現象が緩和され，結 果として超音波度労寿命は通常の疲労寿命に近づくと 考えられる.このことは Ti-6A14V チタン合金を用い た試験で実証されている(1)。一方，超長寿命領域で介 在物が起点となって疲労破壊を起こす高強度材におい ても繰返し速度の影響か明確になっているとはいえな い. 介在物が疲労破壊起点の場合にはき裂准展の機構 を直接観察することは困難であるので，本研究ではま ずフェライト・パーライト組織のき裂進展機構に及ぼ す綝返し速度の影響を調べた。純鉄や軟鋼の疲労破壊

Table 1 Chemical composition of $0.13 \%$ carbon sted (wt\%).

\begin{tabular}{c|c|c|c|c|c|c|c}
\hline $\mathrm{C}$ & $\mathrm{Si}$ & $\mathrm{Mn}$ & $\mathrm{P}$ & $\mathrm{S}$ & $\mathrm{Cl}$ & $\mathrm{Al}$ & $\mathrm{Ni}+\mathrm{Cr}$ \\
\hline 0.13 & 0.22 & 0.39 & 0.013 & 0.022 & 0.09 & 0.01 & 0.10 \\
\hline
\end{tabular}

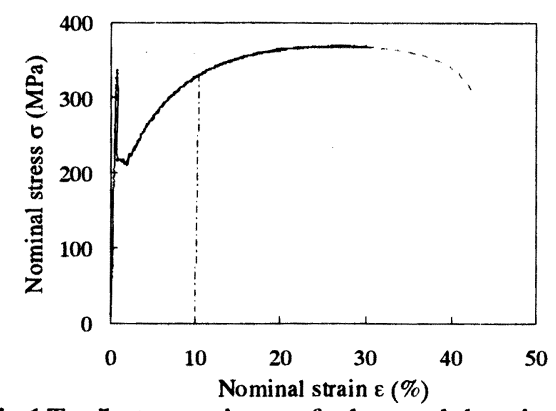

Fig. 1 Tensile stress-strain curve for the annealed specimen of $0.13 \%$ carbon steel. Strain rate $: 56 \times 10^{6} / \mathrm{sec}$.

Table 2 Yield stress and tensile strength of $0.13 \%$ carbon steel.

Strain rate : $56 \times 10^{-6} / \mathrm{sec}$

\begin{tabular}{|c|c|c|}
\hline \hline Upper yield stress $\alpha_{\mathrm{u}}$ & Lower yield streas $\alpha_{\mathrm{s}}$ & Tensile strength $\sigma_{\mathrm{B}}$ \\
\hline $338 \mathrm{MPa}$ & $210 \mathrm{MPa}$ & $370 \mathrm{MPa}$ \\
\hline
\end{tabular}

機構の大部分を占めるき裂准展特性に関して微視的な 観察にもとづいて絽返し速度の影響を調へた研究は見 当たらない. 種々の材料の超長寿命疲労試験て超音波 疲労試験機の使用の妥当性を示すためには，疲労強度 特性における繰返し速度依存性の有無とその基本機構 を明らかにする必要がある。

本研究では，超音波疲労試験機(20k价)および通常の 油圧サーボ引張圧縮度労試馬㑒機(10H飞)を使用して，低 炭素鋼 S10C の疲労強度, 特にき裂准展特性に及ぼす 繰返し速度の影響を明らかにする．試験片には焼鈍し 材に加えて予ひずみ材を使用した。さらに Split Hopkinson 棒法による衝摮圧縮式験を行い，低炭素鋼 における降伏点などの機械的性質のひずみ速度依存性 か疲労破壊機構にどのように影響を及ぼすかを明らか にする.

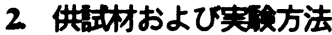

供試材は低炭素鋼 S10Cである．焼鈍し材および 10\%の予ひずみ材を疲労試験片として使用した．表 1 に S10Cの化学成分を示す. 図 1 に焼鈍し材の応 カーひずみ線図を示す. 引張試験では引張強さまで を測定したので，試験片にくびれが発生してから破 断するまでの応力ーひずみ線図の挙動は概略として 推定線で示す. さらに，公称 10\%の予ひずみを予ひ ずみ材に与えて，除荷したときの挙動を一点鎖線で 示す．予ひずみ材の除荷後のひずみは 9.94\%である. 表 2 に S10C の降伏点および引張強さを示す．また， Split Hopkinson棒法による焼鈍し材の衝撃圧縮試験 も行い, 高ひずみ速度での応力ーひずみ線図を測定 した.この実験結果については後で考察する.

図 2 に超音波疲労試験および通常の引張圧縮疲労 試験の試験片形状を示す.き裂進展挙動を観察する ため，焼鈍し材および 10\%の予ひずみ材の試験片中 央部の円周を 2 分割する位置にそれそれ直径, 深さ ともに $100 u \mathrm{~m}$ の 2 つの人工微小穴を導入した. 図 3 に人工微小穴の形状を示す.

超音波疲労試験では試験片形状で試験片に負荷で きる応力の範用が決まる. 焼鈍し材および 10\%の予ひ ずみ材の超音波疲労試験片はそれそれい疲労試験での 負荷応力にあわせて形状を決めた.

焼鈍し材は $9000^{\circ} \mathrm{C} \times 60 \mathrm{~min}$ で熱処理を施した. 試験 片製作後, 表面をバフ研摩し, 真空焼鈍 $\left(600^{\circ} \mathrm{C}\right.$ × 60min)を行った. 焼鈍し材の硬さは $H V=123$ (測定荷 重 $200 \mathrm{gf}, 10$ 点平均, ばらつき $8 \%$ 以下)である。

超音波度労試験での固溶原子による転位の固着およ び加工硬化の影響を調べるために，予ひずみ材の疲労 


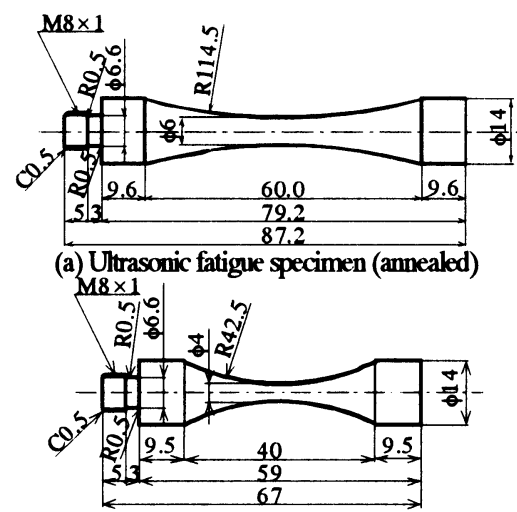

(b) Utrasonic fatigue specimen (10\% pre-strained)

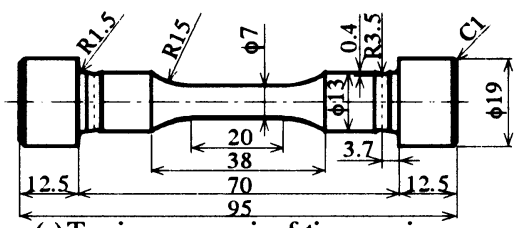

(c) Tension compression fatigue specimen

Fig. 2 Shape and dimensions of specimens; dimensions in $\mathbf{m m}$.

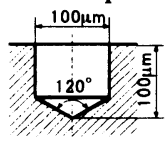

Fig. 3 Dimensions of the small artificial hole.

試験も行った。予ひずみ材は 10\%の引張りひずみを与 えて疲労試験片を製作した後, 試験片表面をエメリー 紙で\#2000 まで研磨し，電解研摩で表面を30um以上除 去した. 予ひずみ材の硬さは $H V=160$ (測定荷重 $200 \mathrm{gg}$ ， 10 点平均, ばらつき $5 \%$ 以下)である. ひずみ時効の影 響を抑えるため, 10\%の予ひずみを与えてから 2 週間 (2×10 min)以内に予ひずみ材の疲労試験を行った.

超音波度労試験は繰返し速度が非常に高いので, 試 験片が発熱する場合がある. 超音波疲労試験中は試験 片温度が 35 C以下に保たれるように, 強制空冷およ ひ超音波振動の負荷と停止を交互に絽返す断続負荷( を行った。断続負荷は超音波振動を負荷時間 200 $400 \mathrm{msec}$ ，停止時間 600-1200msec で調整した. 超音波度 労試験では設定した応力振幅の $80 \%$ 超える綝返し応 力を絽返し数 $N$ としてカウントした.

超音波疲労試験は試験片に縦波(P 波)の定常波を発 生させて疲労試験を行う. 試験片のき裂がある程度長 くなると, 試験片の共振周波数が低下して超音波疲労 試験の繰返し速度も低下し, 最後には超音波疲労試験 機での疲労試験力涃難になるほと繰返し速度が低下す る. 超音波疲労試験では破断までの綝返し数 $N_{\mathrm{f}}$ とし て, 超音波疲労試験開始時の絽返し速度 20k妨から

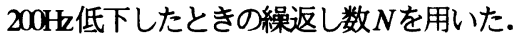

超音波疲労試験では通常, 試験片中央部に発生する 最大応力振幅は渦電流式変位計を使用し, 試験片の端 面変位から算出する.この方法では応力振幅に無視で きない誤差が生じることをあらかじめ予備試験で確認 した. そこで, より正確な応力振幅を求めるために, 予備試験片の中央部にひずみゲージを貼り, 真の応力 振幅を求め, 端面変位から算出した応力振幅との較正 曲線を作成した. 䒠際の疲労試験では端面変位を測定 して応力振幅を算出し，その較正曲線から真の応力振 幅を求めた. 軟鋼の疲労試験ではマク口的には弾性変 形でも無視できない程度の塑性変形が生じていること が考えられる. しかし, 後で詳しく述べるように, 超 音波疲労試験でのき裂准展観察ではき裂周辺のすべり 帯が極めて少ないことから，超音波痩労試験での塑性 変形は通常の引張圧縮度労試験より極めて小さいと考 え,ひずみから応力の算出に際しては弾性変形として 取扱つた.

通常の弓張圧縮度労試験片の周方向を 4 分割する位 置にそれぞれひずみゲージを貼り，取付けの際に試験 片に曲げがかからないようにして疲労試験を行った。

\section{3. 応力集中およひ応力拡大係数に及ほす

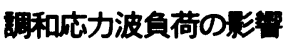

切欠きや介在物などの欠陥の応力集中およびき裂の 応力拡大係数か調和応力波負荷の影響を受ければ，当 然度労強度にもその影響が出てくることが考えられる. これまでこの観点から超音波度労試験の結果を考察し た研究は見当たらない.人工微小穴つき試験片を用い た疲労試験と並行して, 動的理論解析およひ有限要素 法解析を行い, 応力波が応力集中係数および応力拡大 係数に及ぼす影響を明らかにした。

\section{3・1 円孔を持つ無限板の忘力集中に及ほす的和} 㤂力波角荷の影湆 円孔を持つ無限板に調和波( $\mathrm{P}$

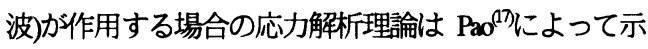
されており, 動的応力集中係数は調和波の波長, ポア ソン比および円孔の直径で決まる. 本研究の解析もそ れに従って行った. 解析モデルはヤング率 $E=206 \mathrm{GPa}$, ポアソン比 $v=03$, 密度 $\rho=7850 \mathrm{kgm}^{3}, \mathrm{P}$ 波の周波数 $f$ $=20 \mathrm{kH}$ として計算した. 図 4 に直径 $2 a$ の円孔を持つ 無限板に周波数 $20 \mathrm{kHz}$ の $\mathrm{P}$ 波の定常波か作用する場合 の応力集中係数と円孔の直径の関系を示す. 円孔の直 径が 10 qum の場合, 円孔縁の $\theta=\pi / 2$ での動的応力集中 係数は $K_{1}=3.00006$ であり, 静的応力集中係数 $K_{\mathrm{f}}=3$ にほ ぼ等しい(図 4).このことから，直径 $100 \mathrm{um}$ の人工微 小穴を持つ丸棒試験片の場合でも動的応力集中と静的 応力集中の差は無視できると考えてよいであろう. 仮 


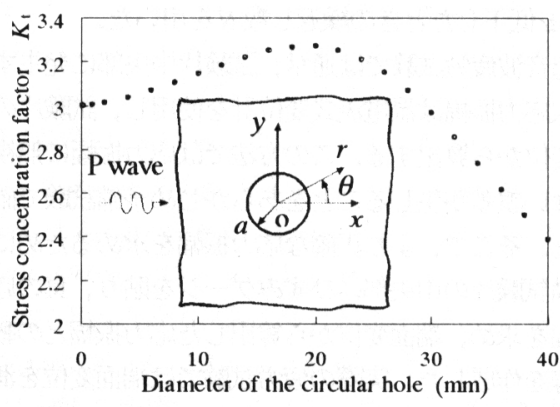

Fig. 4 Stress concentration factor at $\theta=\pi / 2$ of a circular hole under $\mathrm{P}$ wave (20kHz), $E=206 \mathrm{GPa}, v=03, \rho=7850 \mathrm{~kg} / \mathrm{m}^{3}$.

に円孔の直径が $1 \mathrm{~mm}$ の場合でも, 動的応力集中係数 は $K_{\mathrm{f}}=3.00318$ であり, 静的応力集中係数に比べてわず かに 0.11\%高くなるだけである.

\section{$3 \cdot 2$ 球状欠陥を持つ丸棒の応力集中に及ぼす調} 和応力波負荷の影響 有限要素法解析ソフト ANSYS を用いて, 中心に球状欠陥を持つ丸棒に定常 的な調和波( P 波)が作用する場合の忍力集中を解析し た。解析モデルはヤング率 $E=206 \mathrm{GPa}$,ポアソン比 $v=03$, 密度 $\rho=7850 \mathrm{~kg}^{3}$, 調和波の周波数 $f=20 \mathrm{kHz}$, 球状欠陥 の直径 $2 a=100$ um である. 解析では超音波疲労試験と 同じように丸棒中央部で最大応力を発生させるため, 周波数 $f=20 \mathrm{kH} \mathrm{b}$ で丸棒の固有振動数と一致するように 丸棒の直径 $10 \mathrm{~mm}$, 長さ $128 \mathrm{~mm}$ とした. 解析要素は 2 次元 8 節点の軸刘称要素を使用した. 図 5 に有限要素 法解析での要素の分割の様子を示す. 球状欠陥付近の 要素は円周を 128 等分する大きさに分割し，丸棒表面 では丸棒の直径を 40 等分する大きさに要素を分割し て, 丸棒中心の球状欠陥から丸棒表面までの要素がし だいに大きくなるように分割した。

図 6に $z$ 軸方向に調和波(P波)が作用する場合および 静的引張応力が作用する場合の $r$ 軸上の周方向応力 $a_{4}$ を示す。ここで， $\alpha_{z}$ は $z$ 軸方向の公称応力である. 図 6 からわかるように, 調和波が作用する場合のひ、は静 的引張応力が作用する場合とほぼ同じである. 超音波 疲労試験で調和波が伝ぱした場合の直径 $100 \mathrm{um}$ の球 状欠陷縁 $(\psi=\pi / 2)$ の応力集中係数は $K_{\mathrm{r}}=2043$ となり, 静的引張りの場合の応力集中係数 $K_{\mathrm{t}}=2045^{(1)}$ との差は 無視できる程度である. 仮に球状欠陥の直径が $1 \mathrm{~mm}$ の場合でも, 動的応力集中係数は $K_{\mathrm{r}}=2040$ であり, 静 的応力集中係数より $0.25 \%$ 低いだけである.

\section{3・3 円板状き裂の応力拡大係数に及ほす調和応} 力波負荷の影響 図 7 に円板状き裂を持つ無限体 に調和波( $\mathrm{P}$ 波)が伝ばする場合の動的応力拡大係数 $K_{1}$ の計算結果 ${ }^{(9)}$ (2)を示す. 超音波度労試験中に観察され
た最大のき裂長さは $2 a=27 \mathrm{~mm}$ であり, 試験片中のき 裂がこの長さに成長した段皆でも試験片の共振周波数 は低下せず 20k施であった。き裂長さ $2 a=27 \mathrm{~mm}$ の円 板状き裂を持つ無限体に調和波(P 波)が伝ぱする場合, 機械的性質が $E=206 \mathrm{GPa}, v=03, \rho=7850 \mathrm{kgm}^{3}$ では

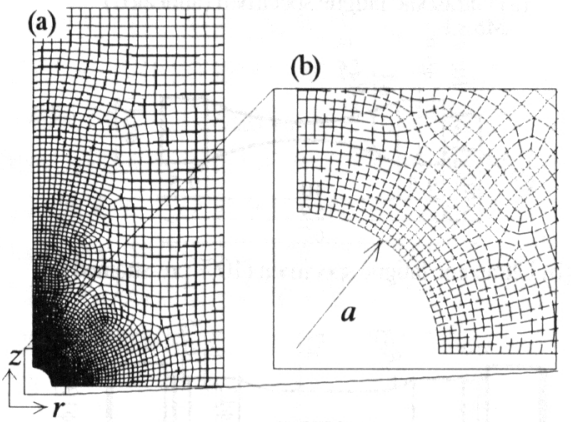

Fig. 5 Finite element mesh. (a) Central part of the round bar. (b) Vicinity of the spherical defect $(2 a=100 \mu \mathrm{m})$.

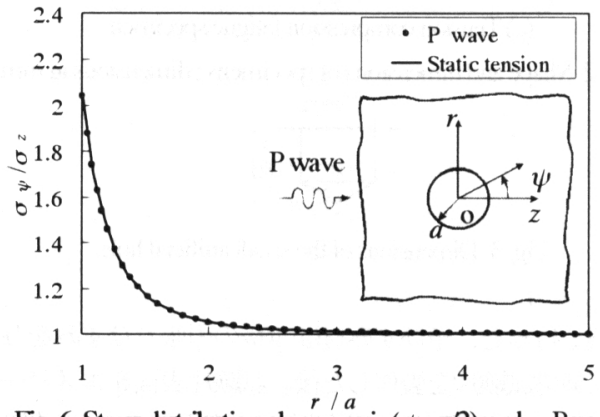

Fig. 6 Stress distribution along $r$-axis $(\psi=\pi / 2)$ under P wave $(f=20 \mathrm{kHz})$ and under static tension, , $2 a=100 \mu \mathrm{m}, E=206 \mathrm{GPa}$, $v=03, \rho=7850 \mathrm{~kg} / \mathrm{m}^{3}, \alpha_{z}$ : remote nominal stress in $z$-direction.

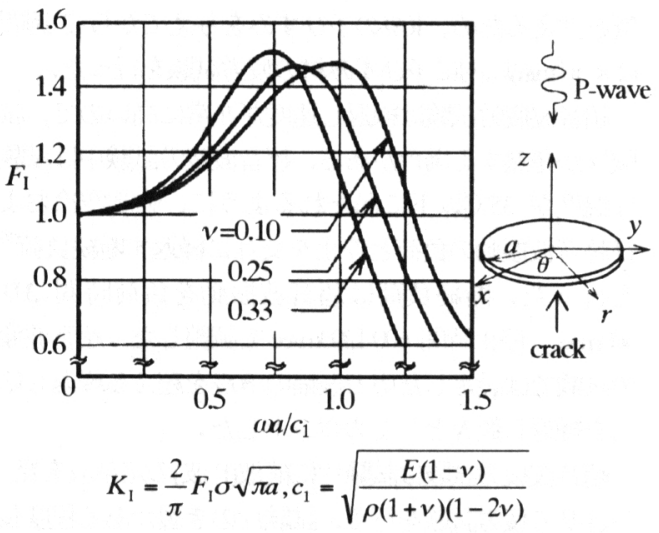

Fig. 7 Stress intensity factor for a penny-shaped crack subjected to a harmonic stress wave ${ }^{(2)}$. $\omega$ :Angular frequency of incident wave, $a$ : Radius of the penny-shaped crack, $c_{1}$ :Longitudinal wave velocity, $E$ :Young's modulus, $v$ :Poisson's ratio, $\rho$ :Mass density, $\sigma:$ Stress amplitude of incident wave. 
$\omega a / c_{1}=285 \times 10^{-2}$ となり, 動的応力拡大係数は静的応力 拡大係数よりも $1 \%$ 末満高いだけである. また, 図 7 に示すように，き裂長さが小さいほど動的応力拡大係 数は静的応力拡大係数に近づくので, 超音波疲労試験 でき裂の応力拡大係数に及ぼす絽返し速度の影響は無 視できると考えられる.

以上の解析結果から，20kł の超音波疲労試験にお いては直径 $100 \mathrm{um}$ 以下の欠陥の応力集中並びにそれ から発生したき裂の応力拡大係数に及ぼす調和応力波 負荷の影響はほとんどないと考えられる。この結果は 本実験結果のみならず, 今後の超音波度労試験結果を 検討する際に役立つ。

\section{4. 実䋡結および考察}

\section{4・1 S-N 線図およひき翌進展速度に及ほす予ひ}

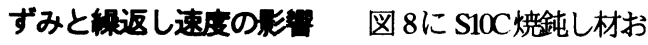
よび 10\%の予ひずみ材の S-N 線図を示す. 焼鈍し材お よび 10\%の予ひずみ材はともに超音波疲労試験 $20 \mathrm{kH}$, ひずみ速度 126 相当)のほうが通常の引張圧縮疲労

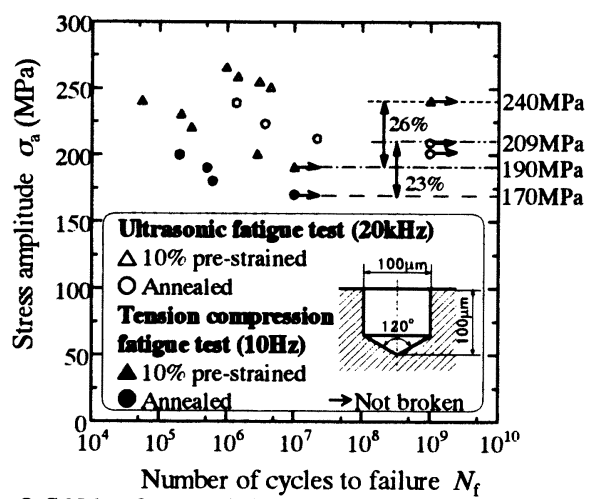

Fig, $8 S$ - $N$ data for annealed and $10 \%$ pre-strained specimens.

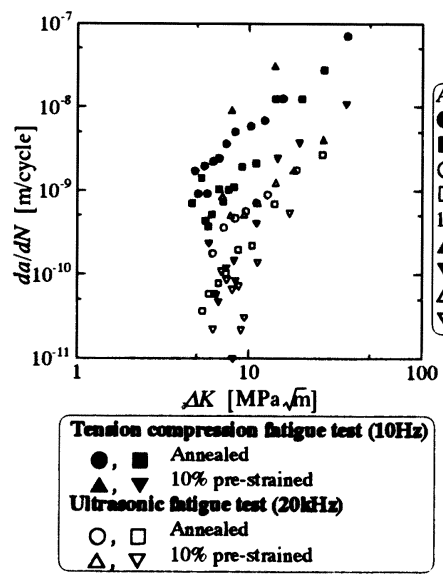

Fig 9 Relationship between the crack growth rate and the stress intensity factor range (10\% pre-strained and annealed). 試験(10t女，ひずみ速度 $63 \times 10^{-2} / \mathrm{sec}$ 相当)よりも疲労 寿命が長く, 疲労限度も高い.それそれの疲労試験の ひずみ速度は応力振幅が $\sigma_{\mathrm{a}}=20 \mathrm{MPa}\left(\varepsilon_{\mathrm{a}}=1 \times 10^{-3}\right)$ の場 合のひずみの正弦波から求めた最大ひずみ速度で近似 している. 通常の弓張圧縮度労試験対する超音波疲労 試験での疲労限度の上昇の割合は焼鈍し材も $10 \%$ の予 ひずみ材もほほ同じ程度である. また，レプリカで初 めてき裂か観察された繰返し数をき裂発生回数 $N_{\mathrm{i}}$ と すると, 超音波疲労試験および通常の引張王縮疲労試 験の $N_{\mathrm{i}}$ は $N_{\mathrm{f}}$ のほぼ 10 分の 1 であった. したがって, 焼鈍し材と 10\%の予ひずみ材はともにき裂発生回数 $N_{\mathrm{i}}$ も超音波度労試験のほうが長い。

図 9 にき裂准展速度 $d a / d N$ と応力拡大係数幅 $\Delta K$ の関 係を示す. 応力拡大係数幅 $\Delta K$ は試験片表面に半円き 裂が存在するものとし(,$\Delta \sigma=2 \sigma$ として求めた.ここ では, 直径, 深さともに $100 \mathrm{um}$ の人工微小穴加発 生したき裂が半円き裂の条件を満たすと考えられる表 面き裂全長が $200 \mathrm{~m}$ 以上のデータを使用している.

図 9からわかるように, き裂准展速度は通常の引張圧 縮度労試験よりも超音波疲労試銩のほうが遅い。これ は図 8 の SN 特性と対応している. さらに, 同一材料 かつ同一試験を行った試験片はどれも応力振幅が高い ほうがき裂進展速度も高い.これは微小き裂の観点か ら次のように説明できる. 応力拡大係数 $K_{1}$ は一般に 式(1)で定義される.

$$
K_{\mathrm{I}}=C \sigma \sqrt{\pi a}
$$

ここで, $C$ :き裂形状や試験片形状に関する係数, $\sigma$ : 無限遠方での応力, $a$ :き裂長さである. 式(1)より $K_{i} か ゙$ 一定で, $\sigma$ 光 $a$ が異なる 2 つ場合を比較すると, $\sigma$ が大きいほうが $a$ は小さい. また, き裂先端周辺の軸 方向応力は厳密には $\sigma_{y}=K_{\mathrm{I}} / \sqrt{2 \pi r}$ ではなく, 式(2)で 表わされる.

$$
\sigma_{y}=\frac{K_{\mathrm{I}}}{\sqrt{2 \pi r}} \cdot \frac{1+r / a}{\sqrt{1+r / 2 a}}
$$

ここで, $r$ :き裂先端からの距離である. $K_{1}$ および $r$ が

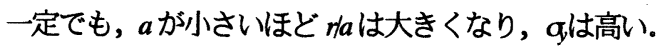
すなわち, $K_{1}$ か一定の場合, 微小き裂近傍の軸方向応 力aは長いき裂よりも高い.したがって, 微小き裂の ほうがき裂先端近傍の応力状態か厳しくなり, き裂進 展速度に図 9のような応力依存性が現れたと考えられ る.

S35Cと S45C鋼 ，Ti6A14Vチタン合金の9疲労き裂 進展特性は通常試験と超音波試験で一致している。こ れに対応して疲労寿命特性も高強度鋼ののと切欠きを 導入した Ti6Al-4Vチタン合金(1)疲労寿命特性も両試 
験で差がない. 一方，本研究の人工微小穴を導入した S10C を含めて低強度鋼ゆ(の)疲労寿命は超音波試験の 方が長くなり, 疲労き裂進展は図 9に示したように遅 くなる. 通常疲労と超音波疲労の相違についてはこれ までき裂発生の観点から検討されてきたが, 本研究の 結果はき裂准展の観点, 特に低強度材では微小き裂准 展の観点からも検討する必要があることを示している. そこで，以下ではき裂先端の変形状態の観察と Splih Hopkinson 棒試験結果に基づいた検討を行う.

$4 \cdot 2$ き裂進展挙動の観察 図 10 に通常の引張 圧縮疲労試験(101飞)および超音波疲労試験(20kH b)での 焼鈍し材のき裂の写真を示す. 通常の引張土縮度労試
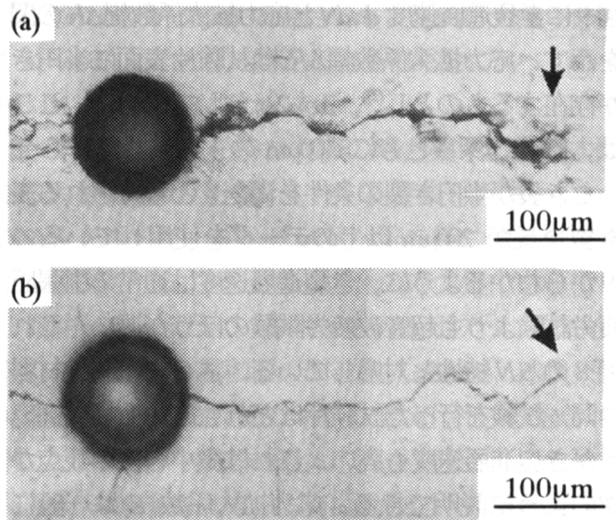

Fig. 10 Crack emanating from a small artificial hole of an annealed specimen. (a) Crack under the conventional tension compression fatigue test, $R=-1, \sigma_{\mathrm{a}}=190 \mathrm{MPa}, N=3.6 \times 10^{5}, N_{\mathrm{f}}$ $=5.10 \times 10^{5}$. (b) Crack under the ultrasonic fatigue test, $R=-1$, $\sigma_{\mathrm{a}}=223 \mathrm{MPa}, N=3.0 \times 10^{6}, N_{\mathrm{f}}=3.73 \times 10^{6}$.
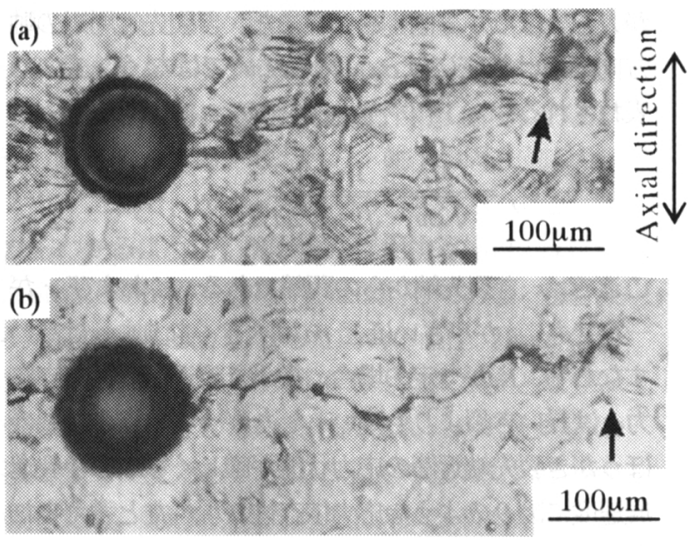

Fig. 11 Crack emanating from a small artificial bole of a $10 \%$ pre-strained specimen. (a) Crack under the conventional tension compression fatigue test, $R=-1, \sigma_{\mathrm{a}}=220 \mathrm{MPa}, N=2.3 \times 10^{5}, N_{\mathrm{f}}$ $=2.93 \times 10^{5}$. (b) Crack under the ultrasonic fatigue test, $R=-1$, $\sigma_{\mathrm{a}}=258 \mathrm{MPa}, N=1.1 \times 10^{6}, N_{\mathrm{f}}=1.44 \times 10^{6}$.
験での焼鈍し材にはき裂周辺の広い範用で多くのすべ り帯か観察された(図 10(a)). 一方, 超音波疲労試験で の焼鈍し材のき裂周辺にはすべり帯がほとんと観察さ れなかった(図 10(b)).

図 11 に通常の弓張圧縮度労試馬験(10セ) )およひ超音波 疲労試験(20k-b)での10\%の予ひずみ材のき裂の写真を 示す。通常の引張土縮疲労試験では狫鈍し材と同様に 10\%の予ひずみ材のき裂周辺の広い範囲ですべり帯か 観察された (図 11(a)). 一方, 超音波疲労試験では $10 \%$ の予ひずみ材のき裂近傍にのみすべり帯か観察された (図 11(b)) - 通常の弓張王縮度労試験に比べて, 焼鈍し 材および 10\%の予ひずみ材はともに超音波疲労試験で のすべり帯の発生が板めて少ない。この違いを明らか にするために，焼鈍し材の疲労試験後のき裂周辺の硬 さを測定した.

図12に人工微小穴緣加試験片円周方向に $100 \mathrm{um}$ 離れた場所での疲労試験後の焼鈍し材のき裂周辺の硬 さ(測定荷重 $50 \mathrm{gg}$ )を示す. 通常の引張土縮度労試験片 $(10 \mathrm{H})$ ) 坑力振幅 $190 \mathrm{MPa}$, 超音波疲労試験片 $(20 \mathrm{kH} b)$ は 応力振幅 239MPa で疲労試験を行った結果である. 通 常の引張圧縮疲労試験後はき裂から軸方向に $300 \mathrm{um}$ の範用で試験片表面の硬さが上昇しており，き裂近傍 の広い範囲で繰返し塑性変形による加工硬化力起こっ ていると考えられる. 一方, 超音波疲労試馬㑒後のき裂 周辺の硬さはほとんど変化していない，このことと図 10 を併せて考えると, 超音波疲労試験における疲労 き裂の周辺ではき裂の進展にともなう塑性変形力゙極め て狭い領域に限定されていることになる.

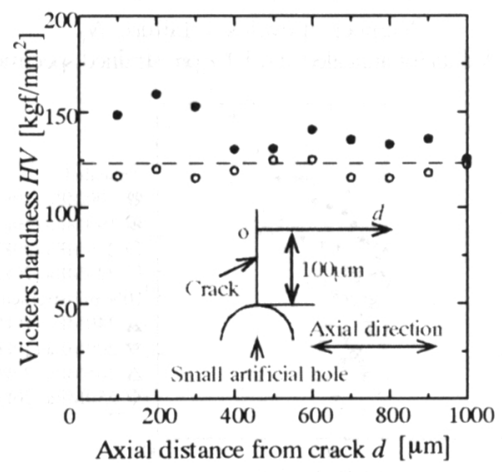

- Tension compression fatigue test $(10 \mathrm{~Hz})$ $\left(\sigma_{\mathrm{a}}=190 \mathrm{MPa}, N_{\mathrm{f}}=5.10 \times 10^{5}\right)$

O Ultrasonic fatigne test $(20 \mathrm{kHz})$ $\left(\sigma_{\mathrm{a}}=239 \mathrm{MPa}, N_{\mathrm{f}}=1.39 \times 10^{6}\right)$

-.-Vickers hardness before fatigue test $(H V=123)$

Fig. 12 Vickers hardness in the vicinity of the crack at the annealed specimen surface. 

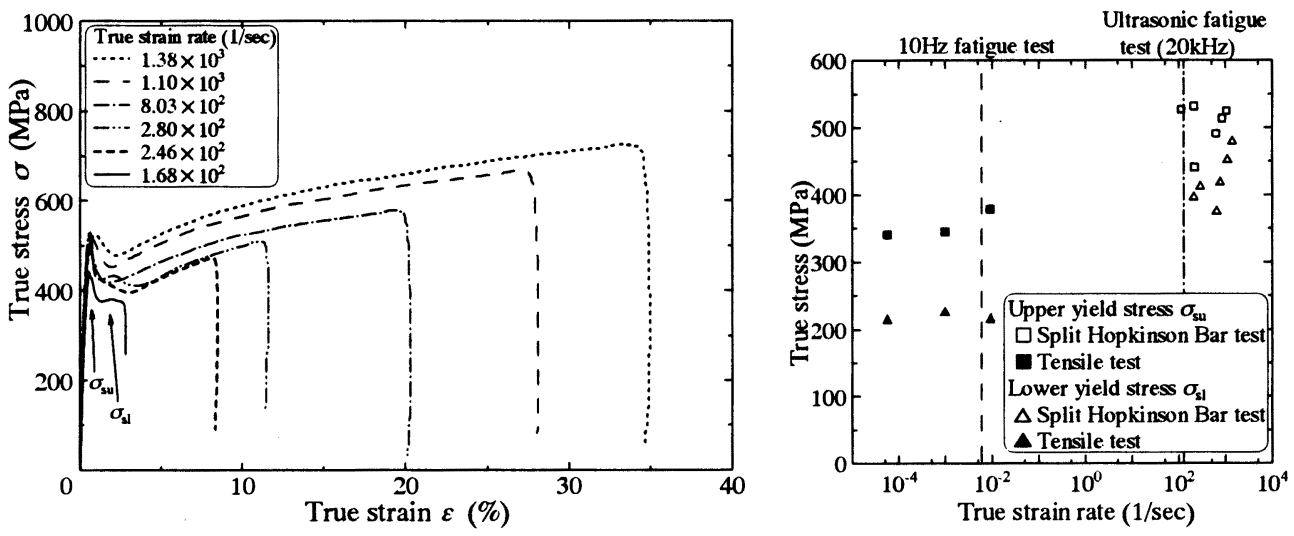

(a) Compressive stress-strain curves for the annealed specimen

(b) Relationship between the yield stress and the strain rate measured by the Split Hopkinson Bar test.

measured by the Split Hopkinson Bar test and the tensile test.

Fig. 13 Dynamic stress-strain behavior of $0.13 \%$ carbon steel in compression.

\section{$4 \cdot 3$ 的㤂カーひずみ曲線の計湘とき裂先端の} 降伏特性一般に，低炭素鋼に多く含まれるフェ ライト組織の結晶構造は体心立方格子である. 体心立 方格子は他の結晶構造に比べてらせん転位のパイエル ス応力が非常に大きく, 運動速度は小さいの. そのた め, フェライト組織は降伏点や引引張強さなどの機械的 性質に対してひずみ速度依存性を持ち，ひずみ速度が 高いほと降伏点および引張り強さも高いことか知られ ているゆの. そこで，本研究では疲労試験に用いたの と同じ材料の動的応力ーひずみ特性を Spli Hopkinson棒 法で計測した.

図 13(a)に Spli Hopkinson 棒法による衝軞厓縮試験で測 定した S10C 烵鈍し材の応力ーひずみ線図を示す. 図 13 の応力およびひずみはそれぞれ真応力, 真ひずみ である. 衝撃圧縮試験のひずみ速度が高いほど, 変形 応力は高い. 図 13(b)に衝擊圧縮試験および引張試験 で得られた上降伏点と下降伏点を示す.ひずみ速度が 高いほど上降伏点およひ下降伏点は高い. 超音波疲労 試験のひずみ速度(126/sec 相当)での上降状点は $500 \mathrm{MPa}$ 程度であり, 通常の引張圧縮疲労試験のひずみ速度 $\left(6.3 \times 10^{2} / \mathrm{sec}\right.$ 相当)での上降伏点 $380 \mathrm{MPa}$ 程度よりも 34\%高い. 超音波疲労試験のひずみ速度では下降伏点 は 400MPa 程度であり, 通常の引張圧縮度労試験のひ ずみ速度では2 $20 \mathrm{MPa}$ 程度である.

以上の焼鈍し材および 10\%の予ひずみ材の結果をま とめて考察すると次のようになる. 超音波度労試験で の応力の負荷は応力波の伝ぱによって生じる. 弾性波 の伝ぱ速度 $V_{\mathrm{e}}$ は $\sqrt{E / \rho}$ に比例する. 通常の引張圧縮 疲労試験のような低ひずみ速度負荷でも超音波疲労試 験のような高ひずみ速度負荷でも, 本研究の条件下で
は応力拡大係数はほぼ等しいので弾性応力分布もほぼ 等しい。しかし，邦祭にはき裂先端で降伏が起こる. 低ひずみ速度ではき裂先端の塑性域は Dugdale モデル で計算できる程度の寸法にまで拡がる，一方，高ひず み速度では塑性域は塑性応力波の伝ぱによって形成さ れ，塑性域寸法は塑性応力波の伝ぱ速度 $V_{\mathrm{p}}$ に影響を 受ける. $V_{\mathrm{p}}$ は $\sqrt{(d \sigma / d \varepsilon) / \rho}$ に比例し, $d \sigma / d \varepsilon$ は動的応 カーひずみ曲線の加工硬化率である. 超音波度労試馬㑒 ではき裂発生直後に塑性応力波の伝ぱにより，き裂先 端で降伏が起こる. 焼鈍し材では降伏点直後に $d \sigma / d \varepsilon$ は 0 に近い極めて小さな值となる. 塑性域で は $V_{\mathrm{p}}$ も0に近い值となり，超音波疲労試験でのき裂先 端の塑性域は拡大が困難となる.この結果が図 10(b) に現れているのである. 一方，10\%の予ひずみ材では $d \sigma / d \varepsilon$ は若干増加するものの $E$ に比べると桁違いに 小さな值となる． 10\%の予ひずみ材では $d \sigma / d \varepsilon$ が焼 鈍し材に比べて若干大きくなるので, 図 11(b)に示す ようなすべり帯がき裂近傍のみに観察されることにな る.このように, 塑性域の形成がき裂先端の狭い領域 に限られるため, 結果的にき裂准展速度か低下し, 疲 労寿命は長くなる.

\section{5. 結}

低炭素鋼 S10C 焼鈍し材および $10 \%$ 予ひずみ材を用 いて超音波疲労試験(20kH女，ひずみ速度 126 kec 相当)お よび通常の油圧サーボによる引張圧縮疲労試験(10甘飞, ひずみ速度 $6.3 \times 10^{-2} / \mathrm{sec}$ 相当)を行った. 動的応力集中 解析および動的応力ーひずみ曲線の計測も行い, 疲労 強度およびき裂准展挙動に及ぼす繰返し速度の影響を 明らかにした。結果は以下のようにまとめられる。 
(1) 円孔を持つ無限板および中心に球状欠陥を持つ丸 棒に 20kセ口 P 波が伝ぱする場合の動的応力集中を解 析した. 直径 $1 \mathrm{~mm}$ 以下の円孔や球状欠宿の動的応力 集中係数は静的応力集中係数とほほ等しい。このこと から，超音波疲労試験では直径 $1 \mathrm{~mm}$ 以下の球状欠陥 の応力集中係数に及ぼす絽返し速度の影響は無視でき る. この結論はその他の久陷や介在物などの影響にも 応用できるものと考えられる.

(2) 円板状き裂を持つ無限体に $20 \mathrm{kH}$ のP P波が伝ぱする 場合の動的拡大係数を計算した. 超音波疲労試験で観 察された最大き裂長さ $2 a=27 \mathrm{~mm}$ が円板状き裂長さで ある場合, 動的応力拡大係数は静的応力拡大係数とほ ほ等しい.き裂が小さいほど動的応力拡大係数は静的 応力拡大係数に近づくので，超音波疲労試験でのき裂 の応力拡大係数に及ぼす繰返し速度の影響は無視でき ると考えられる.

(3) 焼鈍し材および 10\%の予ひずみ材はともに超音波 疲労試験の方が通常の引張圧縮疲労試験よりも疲労寿 命が長く, 疲労限度も高い。また，き裂進展速度は超 音波疲労試験の方が遅い。

(4)Spli Hopkinson 棒法による衝撃圧縮試験により高ひず み速度での応力ーひずみ線図を求めた． S10C はひず み速度が高いほと降伏点および変形応力が高い，これ は S10C に多く含まれるフェライト組織のらせん転位 の運動により引き起こされると考えられる.

(5) 通常の引張圧縮度労試験での焼鈍し材および $10 \%$ の予ひずみ材ともにき裂周辺の広い範用ですべり帯が 観察された. 一方, 超音波疲労試験では焼鈍し材のき 裂近傍にはすべり帯がほとんと観察されず，10\%の予 ひずみ材はき裂近傍のみにすべり帯か観察された. 超 音波疲労試験ではき裂先端の塑性域寸法は塑性応力波 の伝ぱ速度に影響を受ける. 塑性応力波の伝ぱ速度は 加工硬化率の平方根 $\sqrt{d \sigma / d \varepsilon}$ に比例するので，降伏後 の $d \sigma / d \varepsilon$ の值が小さい焼鈍し材では塑性域の拡大が 困難となり，すべり帯は発生しない。一方，10\%の予 ひずみ材では降伏後の $d \sigma / d \varepsilon$ の值が焼鈍し材より若 干増加するためにき裂近傍のみにすべり帯が発生する。 塑性域の形成はき裂先端の狭い 領域に限られるために き裂進展速度が低下し，疲労寿命が長くなる。

\section{辞}

本研究は平成 1418 年度科学研究補助金「特別推進 研究」課題番号 14001002 の交付を受けて行われたもの である. また，著者の一人は日本学術振興会の特別研 究員であり，本研究は科学研究費補助金 (特別研究員 䍒励費) の交付を受けて行ったものであることを記し，
謝意を表する.

Split Hopkinson 棒法による衝擊圧縮試験に御協力い ただいた Eoole Polyechniqueの G. Gary博士に謝意を表す る. また，有益なご討論をいただいた九州大学工学研 究院，松岡三郎助教授にも謝意を表する.

\section{紊文献}

(1) 内藤武志 - 植田秀夫 - 菊池雅男, 材料, 32-361 (1983), 1162-1166.

(2) Naito, T., Ueda, $\mathrm{H}$ and Kikuchi, M, Met. Trans. A, 15A (1984), 1431-1436.

(3) 江村秀樹 - 浅見克敏，機論，55-509, A(1989), 45-50.

(4) 阿部孝行・金澤健二，材料，46-1 (1996)，9-15.

(5) 村上敬宜 - 植田徹 - 野本哲志 - 村上保夫, 機論, 66642, A(2000), 311-319.

(6) Wang Q. Y, Berard, J. Y., Dubarre, A, Baudry, G., Rathery, S. and Bathias, C., Fatigue Fract. Eng. Mater. Struct, $22(1999), 667-672$.

(7) 石井仁・山中一史・東组㯳一郎, 第 25 回疲労シン ポジウム講演論文集, $(2000), 199-202$.

(8) 古谷佳之・松岡三郎・阿部孝行・山口弘一，機論 68-667, A (2002), 99-105.

(9) 阿部孝行 ·古谷佳之 - 松岡三郎, 機論, 70-696, A (2004), 1050-1057.

(10) Ritchie, R O., Davidson, D. L, Boyce, B. L, Campbell, J. P. and Roder, O., Fatigue Fract. Engng. Mater. Struct, 22 (1999), 621-631.

(11) 竹内悦男 - 古谷佳之 - 長島伸夫 - 宮原健介 - 松岡 三郎機論, 70-696, A(2004), 1124-1130.

(12) Mayer, H, Papakyriacou, M, Pippan, R and StanzlTschegg S, Mater. Sci. Eng., A314 (2001), 48-54.

(13) Tsutsumi, N, Shiromoto, A and Murakami, Y, Proc. Inter. Conf.ATEM 2003, (2003), OS11W0374.PDF.

(14) 菊川真・大路清嗣 ・ 小倉敬二 機論, 32-235 (1966), 363-370.

(15) 粟谷丈夫・片桐一宗, 機論, 34261 (1968), 833-841.

(16) Stanzl-Tschegg S. E, Fatigue 96, 3 (1996), 1187, Pergamon Press.

(17) Pao, Y. H, Trans. ASME, J. Appl. Mech, 29 (1962), 299 305.

(18) Timoshenko, S. P. and Goodier, J. N., Theory of Elasticity, (1970), 396-398, McGraw-Hill.

(19) Sih, G. C. and Loeber, J. F, J. Acoust. Soc. Am, 46 (1968), 711-721.

(20) Mal, A K, Inter. J. Eng. Sci, 8 (1970), 381-388. 
(21) Chen, E. P. and Sih, G. C, Elastodynamic crack problems, (1977), 119-212, Noordhoff.

(22) Murakami, Y.; Editor-in-chief, Stress Intensity Factors Handbook, 2 (1987), 1430-1432, Pergamon Press.

(23) Murakami, Y.; Editor-in-chief, Stress Intensity Factors Haundbook, 2 (1987), 659-665, Pergamon Press.
(24) 松尾彰敏・來海博央・江上登・西村繁仁，日本機 械学会2003年度年次大会講演論文集, 137-138.

(25) 加藤雅治, 入門転位論, (2003), 115-117, 裳華房.

(26) Manjoine, M J., Trans. ASME, J.Appl. Mech, 11 (1944), A211-A218.

(27) 石橋正, 金属の強さ, (1961), 23-25, 養賢堂. 